\title{
SPA SERVICES IN HOTEL FACILITIES IN THE LUBLIN PROVINCE THE IMPORTANCE OF HOTEL FACILITIES IN THE PROVISION OF SPA SERVICES IN THE LUBLIN PROVINCE
}

\author{
${ }^{1}$ ANDRZEJ ŚWIECA, ${ }^{2}$ BARTOSZ SKRZYPEK \\ ${ }^{1}$ Maria Curie-Skłodowska University in Lublin, Faculty of Earth Sciences and Spatial Management, \\ Department of Regional Geography and Tourism \\ ${ }^{2}$ PhD studies at Maria Curie-Skłodowska University in Lublin, Faculty of Earth Sciences and Spatial \\ Management, Department of Regional Geography and Tourism
}

Mailing address: Andrzej Świeca, Faculty of Earth Sciences and Spatial Management, Department of Regional Geography and Tourism, 2 cd Kraśnicka Avenue, 20-718 Lublin, tel.: + 4881 5376849, fax: + 4881 5376862, e-mail: andrzej.swieca@poczta.umcs.lublin.pl

\begin{abstract}
Introduction. Apart from basic services, the modern hotel industry provides a number of additional services, including those having to do with wellness. This article attempts to provide a general description of spa services in selected hotel facilities in the Lublin Province in Poland. Material and methods. Data on the size of the accommodation base, its diversity, and its occupancy by tourists were obtained from the official statistical publications of the Polish Central Statistical Office (GUS). The paper presents the results of research on quantitative and structural transformations of mass accommodation facilities in the years 2000-2013. Particular attention was paid to spa hotels. Information on their profile and offer of balneological and wellness treatments was collected by means of a diagnostic survey in the form of an interview (primary source) and the exploration of websites (secondary source). Results and conclusions. According to the data provided by the Central Statistical Office, in 2013 there were a total of 285 mass accommodation facilities in the Lublin Province (accounting for $2.9 \%$ of all facilities in Poland), which constitutes $8.0 \%$ of the territory of Poland and is inhabited by $5.6 \%$ of the country's population. The facilities were able to receive approximately 18,700 guests $(2.7 \%$ of the total accommodation capacity of Poland). Every fourth mass accommodation facility in the Lublin Province was a hotel. This type of accommodation base was represented particularly by facilities of lower categories (3, 2, and 1 star hotels), and it accounted for approximately $27 \%$ of the total accommodation capacity of the Lublin Province. Hotels and guest houses offering spa services in addition to accommodation constituted $19.5 \%$ of the total number of hotel facilities in the Lublin Province. They were particularly concentrated in Lublin and the towns of the Puławy (Puławski) District, such as Kazimierz Dolny and Nałęczów. Spa services provided in hotel facilities can become an important product intensifying the use of tourist space in the Lublin Province.
\end{abstract}

Key words: accommodation base, hotels, spa services, Lublin Province

\section{Introduction}

Hotel facilities offering spa services have become a permanent feature of the Polish market of tourism services, expanding it to include new types of services and possibilities of meeting the needs of tourists. The categorisation of spa facilities according to the services provided is extensive [1, 2, 3]. A traditional spa product involves treatments which make use of the medicinal properties of waters, both those based on their specific mineral composition (as in the case of peloid or brine, for example) and those involving specific applications of water in various forms in saunas, swimming pools, baths, or hydro massage [4]. There are approximately 70 types of treatment, exercise, and therapy that are practised in water [5]. New spa products combine balneological treatments with modern forms of wellness and attractive treatments typical of spa and wellness tourism [4]. Facilities classified as spas also offer various forms of healing massage and physiotherapy $[1,6]$. As part of pro-health tourism, spas can take different forms $[1,6]$. There are centres in which the patient spends several hours per day several days a week (day spas) and those where they spend several up to a dozen hours over one day (destination spas or resort/hotel spas).

The term "spa" is inseparably associated with the term "wellness", frequently identified and used in combination with or instead of the term spa [7, 8]. According to D. Dryglas [7], spa as a service is only one of the forms of regenerating a person's psychophysical condition included in wellness philosophy. The components of the term "spa and wellness" are complementary and share a single objective, namely enhancing the vitality of the organism [6].

According to the relevant literature [9], the idea of spa is in line with the pro-heath activity of modern societies. An increasing number of people are including various types of treatments improving their physical and psychological condition in their holiday plans [8]. The role of spa centres in the promotion of a healthy lifestyle was analysed by A. Mroczek [6] and A. Maj [10]. Spas were also discussed in the context of the state of modern health tourism in papers by I. Łęcka [11], A.P. LubowieckiVikuk [8], and D. Dryglas [7], in the collective work by M. Januszewska, E. Nawrocka, and S. Oparka [12], and by J. Owsiak [13]. 
The profiles of tourists who visit spa facilities and reasons for visiting them were analysed by A. H. N. Mak, K. K. F Wong, and R. C. Y Chang [14]. A description of spa facilities as an innova tive health tourism product constituting a source of competitive advantage in the Polish and global market of spa services can be found in the paper by D. Dryglas [7], while the development of spa centres in the USA is presented in the work of S. E. Spivack [15]. As far as the Lublin Province is concerned, an analysis of the possibilities of developing health tourism in the context of the smart specialisation of the Province in medical and prohealth services is provided in the paper by A. Tucki and A. Hadzik [16].

In Poland, civilisational transformations had a great impact on the growing popularity of spa services, including the political transformation, the integration of Poland with European structures, and the opening of the borders [7]. In Poland, the term "spa" is not only used by facilities a priori based on the idea of spa; it is also ascribed to beauty salons, wellness centres, and accommodation facilities [2, 3, 8, 13]. The importance of spa services in the development of the hotel industry was analysed by J. Hałaczkiewicz [5] and J. Wojnarowski [17]. The paper by J. Hałaczkiewicz [5] provided information regarding the level of the quality of spa services in selected hotels in Poland, Germany, the UK, and the USA. J. Wojnarowski [17] emphasised the perspectives for the development of hotel facilities specialising as medical spa centres. On the other hand, the paper by E. Szczepanowska, B. Kaczor, and K. Pawełek focused on the type of facilities and services provided by Polish-German spa hotels [2].

The aim of this paper is to present quantitative changes regarding mass accommodation facilities in the Lublin Province in the years 2000-2013, with particular consideration of hotels, followed by a determination of the current state and offer of hotel facilities providing spa services. The main motivation for undertaking the study was the scarcity of literature referring to the Lublin Province [16]. In order to meet the aim of the article, descriptions of the accommodation base in the Lublin Province and of hotel facilities offering spa services were examined. A detailed analysis was conducted concerning the range of services provided by the hotel facilities. The quality criterion adopted was based on a list of 22 forms of therapy recognised as components of good quality spa services by W. Kasprzak and A. Mańkowska [9].

\section{Material and methods}

The hotel facilities in the Lublin Province were described in the context of the current state of mass accommodation facilities. The statistical material describing both the size of the accommodation base and its diversity as well as its occupancy by tourists was obtained from the official statistical publications of the Central Statistical Office [18]. The paper describes the mass accommodation facilities in Poland, their size, and the changes that took place in the years 2000-2013. The obtained data provided a basis for identifying facilities at the district scale. A detailed analysis of the hotel facilities, including those offering spa services, was carried out.

Information on 440 facilities potentially qualified as spas functioning in the Lublin Province was obtained from commonly accessible sources and databases of the Central Record of Hotel Facilities as well as the Panorama Firm and Polskie Książki Telefoniczne company directories [19, 20, 21]. The respondents were further identified based on a CATI telephone survey [22]. The interviews were prepared based on a questionnaire developed in accordance with the rules proposed by T. Sztabiński et al. [23], and a total of 94 interviews were conducted. In order to be classified as a spa facility, a facility needed to provide at least two out of three groups of services: massage, dermatological treatments, and body treatments, e.g. hydrotherapy, pursuant to the guidelines of the International Spa and Fitness Association (ISPA) [1]. The analysis covered a total of 26 facilities (fig. 1) meeting the condition of providing spa treatments with an accommodation option (resort and hotel spas and destination spas) [5]. The description of the facilities included data collected in the diagnostic survey by means of direct interviews with managers and directors (27 interviews in total). The indepth interview conducted using a partially standardised questionnaire prepared based on papers by W. Kasprzak and A. Mańkowska [9] made it possible to obtain information on the profile, accommodation capacity, and offer of wellness services of a given facility.

\section{Results}

\section{Accommodation base as the primary indicator of the accommodation capacity of the facilities in the Lublin Province}

According to the data of the Central Statistical Office [18], in 2013 the Lublin Province had 285 mass accommodation facilities (2.9\% of facilities in Poland), with a total accommodation capacity of 18,668 guests, which constitutes $2.7 \%$ of the capacity of all facilities in Poland (tab. 1). Four cities with district status, namely Lublin, Zamość, Chełm, and Biała Podlaska, had a total of 55 facilities $-19.3 \%$ of the total number of facilities in the Lublin Province. The remaining districts with a relatively high number of facilities included the Puławy (Puławski) District (44 facilities), Włodawa (Włodawski) District (37), and Zamość (Zamojski) District (24). In the main cities (former capitals of the provinces that existed prior to their inclusion in the Lublin Province following the administrative reform in 1999) and in the three aforementioned districts, there was a total number of 160 mass accommodation facilities in 2013, i.e. $56.1 \%$ of facilities in the Lublin Province. The remaining 17 districts in the Lublin Province featured a scarce offer of accommodation facilities, with the lowest number of facilities in the Kraśnik (Kraśnicki) District (1 facility) and the Ryki (Rycki), Radzyń Podlaski (Radzyński), Świdnik (Świdnicki), and Krasnystaw (Krasnostawski) Districts (4 facilities in each).

The distribution of accommodation in the Lublin Province remained similar considering its capacity. Cities with district status offered a capacity of 4,204 guests $(22.5 \%$ of the capacity of the Province). The Puławy (Puławski), Włodawa (Włodawski), and Zamość (Zamojski) Districts offered a total capacity of 8,096 of guests $(43.4 \%)$. The highest mass accommodation capacity for the end of 2013 among the 24 districts of the Lublin Province was recorded for the following districts and cities: the Puławy (Puławski) District - 4,249 (22.8\%), the Włodawa (Włodawski) District - 2,400 (12.8\%), the city of Lublin - 2,195 (11.8\%), the Zamość (Zamojski) District - 1,447 (7.8\%), the Lubartów (Lubartowski) District - 1,103 (5.9\%), the city of Zamość - 1,070 (5.7\%), and the Biała Podlaska (Bialski) District - 918 (4.9\%). The accommodation capacities of the cities of Kraśnik and Radzyń Podlaski (below 100 guests) and the Ryki (Rycki) and Krasnystaw (Krasnostawski) Districts (below 150 guests) were very limited.

In 2013, out of approximately 743,000 tourists using the services of mass accommodation facilities (tab. 2), the highest number of guests were accommodated in facilities located in Lublin (25.5\%) and the Puławy (Puławski) District (20.3\%). The highest number of sold accommodation places was also recorded in those districts: approximately 291,000 (18.8\%) and approximately 585,000 (37.8\%), respectively. 
Table 1. Accommodation base in particular districts and cities with district status in the Lublin Province in 2000 and 2013

\begin{tabular}{|c|c|c|c|c|}
\hline \multirow{2}{*}{$\begin{array}{l}\text { Selected accommodation } \\
\text { facilities in particular } \\
\text { districts and cities }\end{array}$} & \multicolumn{2}{|c|}{$\begin{array}{l}\text { Number of facilities } \\
\text { in }\end{array}$} & \multicolumn{2}{|c|}{$\begin{array}{l}\text { Accommodation capacity } \\
\text { in }\end{array}$} \\
\hline & 2000 & 2013 & 2000 & 2013 \\
\hline \multicolumn{5}{|l|}{ Biała Podlaska (Bialski) District } \\
\hline mass accommodation facilities & 21 & 19 & 565 & 918 \\
\hline including hotel facilities & 3 & 9 & 138 & 439 \\
\hline including hotels & 1 & 4 & 42 & 247 \\
\hline \multicolumn{5}{|l|}{ Parczew (Parczewski) District } \\
\hline mass accommodation facilities & 19 & 10 & 961 & 402 \\
\hline including hotel facilities & 0 & 2 & 0 & 59 \\
\hline including hotels & 0 & 0 & 0 & 0 \\
\hline \multicolumn{5}{|l|}{ Radzyń Podlaski (Radzyński) District } \\
\hline mass accommodation facilities & 7 & 4 & 114 & 73 \\
\hline including hotel facilities & 0 & 2 & 0 & 40 \\
\hline including hotels & 0 & 0 & 0 & 0 \\
\hline \multicolumn{5}{|l|}{ Włodawa (Włodawski) District } \\
\hline mass accommodation facilities & 66 & 37 & 4147 & 2400 \\
\hline including hotel facilities & 3 & 3 & 123 & 225 \\
\hline including hotels & 1 & 1 & 18 & 134 \\
\hline \multicolumn{5}{|l|}{ Biłgoraj (Bilgorajski) District } \\
\hline mass accommodation facilities & 11 & 11 & 448 & 387 \\
\hline including hotel facilities & 1 & 6 & 64 & 234 \\
\hline including hotels & 1 & 2 & 64 & 94 \\
\hline \multicolumn{5}{|l|}{ Chełm (Chełmski) District } \\
\hline mass accommodation facilities & 10 & 6 & 492 & 388 \\
\hline including hotel facilities & 0 & 3 & 0 & 155 \\
\hline including hotels & 0 & 0 & 0 & 0 \\
\hline \multicolumn{5}{|c|}{ Hrubieszów (Hrubieszowski) District } \\
\hline mass accommodation facilities & 2 & 3 & 59 & 136 \\
\hline including hotel facilities & 0 & 2 & 0 & 73 \\
\hline including hotels & 0 & 0 & 0 & 0 \\
\hline \multicolumn{5}{|c|}{ Kransnystaw (Krasnostawski) District } \\
\hline mass accommodation facilities & 5 & 4 & 228 & 137 \\
\hline including hotel facilities & 2 & 4 & 45 & 137 \\
\hline including hotels & 1 & 2 & 20 & 43 \\
\hline \multicolumn{5}{|c|}{ Tomaszów Lubelski (Tomaszowski) District } \\
\hline mass accommodation facilities & 19 & 10 & 688 & 954 \\
\hline including hotel facilities & 1 & 3 & 81 & 138 \\
\hline including hotels & 1 & 1 & 81 & 40 \\
\hline \multicolumn{5}{|l|}{ Zamość (Zamojski) District } \\
\hline mass accommodation facilities & 32 & 24 & 1648 & 1447 \\
\hline including hotel facilities & 4 & 5 & 101 & 322 \\
\hline including hotels & 0 & 3 & 0 & 209 \\
\hline \multicolumn{5}{|l|}{ Lubartów (Lubartowski) District } \\
\hline mass accommodation facilities & 24 & 16 & 3034 & 1103 \\
\hline including hotel facilities & 2 & 3 & 111 & 72 \\
\hline including hotels & 2 & 1 & 111 & 30 \\
\hline \multicolumn{5}{|l|}{ Lublin (Lubelski) District } \\
\hline mass accommodation facilities & 2 & 13 & 42 & 489 \\
\hline including hotel facilities & 2 & 9 & 42 & 356 \\
\hline including hotels & 1 & 7 & 27 & 317 \\
\hline \multicolumn{5}{|l|}{ Lęczna (Lęczyński) District } \\
\hline mass accommodation facilities & 7 & 5 & 546 & 271 \\
\hline including hotel facilities & 0 & 1 & 0 & 72 \\
\hline including hotels & 0 & 1 & 0 & 72 \\
\hline
\end{tabular}

\begin{tabular}{|c|c|c|c|c|}
\hline \multirow{2}{*}{$\begin{array}{l}\text { Selected accommodation } \\
\text { facilities in particular } \\
\text { districts and cities }\end{array}$} & \multicolumn{2}{|c|}{$\begin{array}{l}\text { Number of facilities } \\
\text { in }\end{array}$} & \multicolumn{2}{|c|}{$\begin{array}{l}\text { Accommodation capacity } \\
\text { in }\end{array}$} \\
\hline & 2000 & 2013 & 2000 & 2013 \\
\hline \multicolumn{5}{|l|}{ Świdnik (Świdnicki) District } \\
\hline mass accommodation facilities & 2 & 4 & 91 & 149 \\
\hline including hotel facilities & 0 & 3 & 0 & 101 \\
\hline including hotels & 0 & 2 & 0 & 76 \\
\hline \multicolumn{5}{|l|}{ Janów Lubelski (Janowski) District } \\
\hline mass accommodation facilities & 7 & 5 & 668 & 394 \\
\hline including hotel facilities & 2 & 3 & 71 & 146 \\
\hline including hotels & 2 & 3 & 71 & 146 \\
\hline \multicolumn{5}{|l|}{ Kraśnik (Kraśnicki) District } \\
\hline mass accommodation facilities & 2 & 1 & 61 & 37 \\
\hline including hotel facilities & 2 & 1 & 61 & 37 \\
\hline including hotels & 1 & 1 & 28 & 37 \\
\hline \multicolumn{5}{|l|}{ Kuków (Lukowski) District } \\
\hline mass accommodation facilities & 8 & 5 & 576 & 228 \\
\hline including hotel facilities & 0 & 2 & 0 & 102 \\
\hline including hotels & 0 & 1 & 0 & 66 \\
\hline \multicolumn{5}{|l|}{ Opole Lubelskie (Opolski) District } \\
\hline mass accommodation facilities & 2 & 5 & 121 & 186 \\
\hline including hotel facilities & 0 & 4 & 0 & 161 \\
\hline including hotels & 0 & 3 & 0 & 141 \\
\hline \multicolumn{5}{|l|}{ Puławy (Puławski) District } \\
\hline mass accommodation facilities & 25 & 44 & 2107 & 4249 \\
\hline including hotel facilities & 9 & 21 & 593 & 1308 \\
\hline including hotels & 7 & 12 & 544 & 857 \\
\hline \multicolumn{5}{|l|}{ Ryki (Rycki) District } \\
\hline mass accommodation facilities & 0 & 4 & 0 & 116 \\
\hline including hotel facilities & 0 & 4 & 0 & 116 \\
\hline including hotels & 0 & 0 & 0 & 0 \\
\hline \multicolumn{5}{|l|}{ Biała Podlaska } \\
\hline mass accommodation facilities & 12 & 6 & 373 & 475 \\
\hline including hotel facilities & 3 & 5 & 84 & 207 \\
\hline including hotels & 3 & 4 & 84 & 166 \\
\hline \multicolumn{5}{|l|}{ Chelm } \\
\hline mass accommodation facilities & 9 & 7 & 508 & 464 \\
\hline including hotel facilities & 2 & 4 & 228 & 320 \\
\hline including hotels & 2 & 3 & 228 & 196 \\
\hline \multicolumn{5}{|l|}{ Lublin } \\
\hline mass accommodation facilities & 21 & 27 & 2748 & 2195 \\
\hline including hotel facilities & 8 & 22 & 1187 & 1938 \\
\hline including hotels & 5 & 16 & 997 & 1470 \\
\hline \multicolumn{5}{|l|}{ Zamość } \\
\hline mass accommodation facilities & 15 & 15 & 807 & 1070 \\
\hline including hotel facilities & 5 & 12 & 317 & 730 \\
\hline including hotels & 4 & 9 & 280 & 601 \\
\hline \multicolumn{5}{|l|}{ TOTAL } \\
\hline mass accommodation facilities & 328 & 285 & 21032 & 18668 \\
\hline including hotel facilities & 49 & 133 & 3246 & 7488 \\
\hline including hotels & 32 & 76 & 2595 & 4942 \\
\hline
\end{tabular}


Table 2. Occupancy of the accommodation base in the districts of the Lublin Province in 2000 and 2013

\begin{tabular}{|c|c|c|c|c|}
\hline \multirow{2}{*}{$\begin{array}{l}\text { Selected accommodation } \\
\text { facilities in particular } \\
\text { districts and cities }\end{array}$} & \multicolumn{2}{|c|}{$\begin{array}{l}\text { Number of facilities } \\
\text { in }\end{array}$} & \multicolumn{2}{|c|}{$\begin{array}{c}\text { Accommodation capacit } \\
\text { in }\end{array}$} \\
\hline & 2000 & 2013 & 2000 & 2013 \\
\hline \multicolumn{5}{|l|}{ Biała Podlaska (Bialski) District } \\
\hline mass accommodation facilities & 14278 & 51781 & 18079 & 61242 \\
\hline including hotel facilities & 4694 & 49192 & 5311 & 56289 \\
\hline including hotels & 1851 & 34821 & 1883 & 36809 \\
\hline \multicolumn{5}{|l|}{ Parczew (Parczewski) District } \\
\hline mass accommodation facilities & 9718 & 4844 & 27891 & 13931 \\
\hline including hotel facilities & 0 & 2197 & 0 & 3944 \\
\hline including hotels & 0 & 870 & 0 & 1034 \\
\hline \multicolumn{5}{|c|}{ Radzyń Podlaski (Radzyński) District } \\
\hline mass accommodation facilities & 3833 & 3542 & 4427 & 4194 \\
\hline including hotel facilities & 0 & 3131 & 0 & 3595 \\
\hline including hotels & 0 & 0 & 0 & 0 \\
\hline \multicolumn{5}{|l|}{ Włodawa (Włodawski) District } \\
\hline mass accommodation facilities & 24370 & 32841 & 152256 & 79317 \\
\hline including hotel facilities & 3988 & 6233 & 7749 & 10903 \\
\hline including hotels & 637 & 4004 & 770 & 5980 \\
\hline \multicolumn{5}{|l|}{ Biłgoraj (Biłgorajski) District } \\
\hline mass accommodation facilities & 4038 & 7032 & 13489 & 17799 \\
\hline including hotel facilities & 1625 & 5794 & 1937 & 14691 \\
\hline including hotels & 1625 & 4246 & 1937 & 5048 \\
\hline \multicolumn{5}{|l|}{ Chełm (Chełmski) District } \\
\hline mass accommodation facilities & 7954 & 8915 & 12761 & 9638 \\
\hline including hotel facilities & 0 & 8859 & 0 & 9571 \\
\hline including hotels & 0 & 0 & 0 & 0 \\
\hline \multicolumn{5}{|c|}{ Hrubieszów (Hrubieszowski) District } \\
\hline mass accommodation facilities & 2178 & 628 & 2569 & 4342 \\
\hline including hotel facilities & 0 & 2722 & 0 & 3613 \\
\hline including hotels & 0 & 595 & 0 & 1005 \\
\hline \multicolumn{5}{|c|}{ Kransnystaw (Krasnostawski) District } \\
\hline mass accommodation facilities & 4961 & 7453 & 9706 & 13212 \\
\hline including hotel facilities & 3684 & 7197 & 5779 & 11978 \\
\hline including hotels & 1688 & 2860 & 2538 & 5520 \\
\hline \multicolumn{5}{|c|}{ Tomaszów Lubelski (Tomaszowski) District } \\
\hline mass accommodation facilities & 25853 & 13838 & 59880 & 36418 \\
\hline including hotel facilities & 7235 & 9684 & 8966 & 14344 \\
\hline including hotels & 5723 & 5882 & 7454 & 6596 \\
\hline \multicolumn{5}{|l|}{ Zamość (Zamojski) District } \\
\hline mass accommodation facilities & 23737 & 32905 & 64673 & 79630 \\
\hline including hotel facilities & 0 & 12007 & 9109 & 26485 \\
\hline including hotels & 4440 & 14637 & 0 & 23043 \\
\hline \multicolumn{5}{|l|}{ Lubartów (Lubartowski) District } \\
\hline mass accommodation facilities & 12729 & 9979 & 59465 & 35631 \\
\hline including hotel facilities & 1603 & 2804 & 3174 & 5923 \\
\hline including hotels & 1603 & 1544 & 3174 & 3332 \\
\hline \multicolumn{5}{|l|}{ Lublin (Lubelski) District } \\
\hline mass accommodation facilities & 3379 & 36521 & 4876 & 46126 \\
\hline including hotel facilities & 3379 & 35052 & 4876 & 42096 \\
\hline including hotels & 2083 & 31537 & 3263 & 37579 \\
\hline \multicolumn{5}{|l|}{ Kęczna (Łęczyński) District } \\
\hline mass accommodation facilities & 1424 & 1552 & 9304 & 5474 \\
\hline including hotel facilities & 0 & 467 & 0 & 1372 \\
\hline including hotels & 0 & 467 & 0 & 1372 \\
\hline
\end{tabular}

\begin{tabular}{|c|c|c|c|c|}
\hline \multirow{2}{*}{$\begin{array}{l}\text { Selected accommodation } \\
\text { facilities in particular } \\
\text { districts and cities }\end{array}$} & \multicolumn{2}{|c|}{$\begin{array}{l}\text { Number of facilities } \\
\text { in }\end{array}$} & \multicolumn{2}{|c|}{$\begin{array}{l}\text { Accommodation capacity } \\
\text { in }\end{array}$} \\
\hline & 2000 & 2013 & 2000 & 2013 \\
\hline \multicolumn{5}{|l|}{ Świdnik (Świdnicki) District } \\
\hline mass accommodation facilities & 3306 & 7636 & 7201 & 15155 \\
\hline including hotel facilities & 0 & 3777 & 0 & 9103 \\
\hline including hotels & 0 & 3036 & 0 & 8129 \\
\hline \multicolumn{5}{|c|}{ Janów Lubelski (Janowski) District } \\
\hline mass accommodation facilities & 9570 & 18485 & 24483 & 39078 \\
\hline including hotel facilities & 6705 & 11608 & 7287 & 15763 \\
\hline including hotels & 6705 & 11608 & 7287 & 15763 \\
\hline \multicolumn{5}{|l|}{ Kraśnik (Kraśnicki) District } \\
\hline mass accommodation facilities & 8312 & 4547 & 8684 & 4762 \\
\hline including hotel facilities & 8312 & 4547 & 8684 & 4762 \\
\hline including hotels & 6105 & 4547 & 6105 & 4762 \\
\hline \multicolumn{5}{|l|}{ Luków (Lukowski) District } \\
\hline mass accommodation facilities & 6592 & 9845 & 48054 & 16641 \\
\hline including hotel facilities & 0 & 7499 & 0 & 11449 \\
\hline including hotels & 0 & 3378 & 0 & 5322 \\
\hline \multicolumn{5}{|l|}{ Opole Lubelskie (Opolski) District } \\
\hline mass accommodation facilities & 881 & 6239 & 4169 & 12398 \\
\hline including hotel facilities & 0 & 6159 & 0 & 12133 \\
\hline including hotels & 0 & 6022 & 0 & 11688 \\
\hline \multicolumn{5}{|l|}{ Puławy (Puławski) District } \\
\hline mass accommodation facilities & 83922 & 151103 & 352661 & 584201 \\
\hline including hotel facilities & 43543 & 72400 & 78004 & 112676 \\
\hline including hotels & 41324 & 50554 & 72110 & 77516 \\
\hline \multicolumn{5}{|l|}{ Ryki (Rycki) District } \\
\hline mass accommodation facilities & 0 & 6756 & 0 & 8088 \\
\hline including hotel facilities & 0 & 6756 & 0 & 8088 \\
\hline including hotels & 0 & 0 & 0 & 0 \\
\hline \multicolumn{5}{|l|}{ Biała Podlaska } \\
\hline mass accommodation facilities & 17646 & 30216 & 27421 & 37541 \\
\hline including hotel facilities & 3539 & 28890 & 4690 & 31892 \\
\hline including hotels & 3539 & 26246 & 4690 & 27627 \\
\hline \multicolumn{5}{|l|}{ Chelm } \\
\hline mass accommodation facilities & 17140 & 18670 & 31003 & 53867 \\
\hline including hotel facilities & 7538 & 14199 & 11591 & 44471 \\
\hline including hotels & 7538 & 9263 & 11591 & 15679 \\
\hline \multicolumn{5}{|l|}{ Lublin } \\
\hline mass accommodation facilities & 130300 & 192239 & 312043 & 290687 \\
\hline including hotel facilities & 87988 & 185123 & 188269 & 276569 \\
\hline including hotels & 73968 & 157915 & 162409 & 222249 \\
\hline \multicolumn{5}{|l|}{ Zamość } \\
\hline mass accommodation facilities & 51156 & 91863 & 68116 & 85094 \\
\hline including hotel facilities & 35070 & 87410 & 28861 & 75425 \\
\hline including hotels & 17535 & 41196 & 26655 & 63988 \\
\hline \multicolumn{5}{|l|}{ TOTAL } \\
\hline mass accommodation facilities & 467277 & 742674 & 1323211 & 1546378 \\
\hline including hotel facilities & 218903 & 573707 & 374287 & 807135 \\
\hline including hotels & 176364 & 415228 & 311866 & 580041 \\
\hline
\end{tabular}


The dynamics of the development of the accommodation base in the Lublin Province in the years 2000-2013 (tab. 1) show a decrease by $13.1 \%$ in the number of mass accommodation facilities. In comparison to 2000, in 2013 guest houses and youth hostels stopped operating. The number of the following facilities was reduced: holiday centres (by 60.8\%), summer camp centres (by 61.5\%), holiday cabin complexes (by 35.0\%), camp sites (by 66.7\%), and camp sites for tents (by 83.3\%). It is worth emphasising that at the same time there was an increase in the number of hotel facilities. An analysis of the changes in the accommodation base in the years 2000-2013 shows that although the total accommodation capacity decreased by $12.5 \%$, this decrease resulted particularly from a fall in the number of offers of lower standard. The change in preferences regarding the forms of tourism and recreation caused a considerable reduction of the accommodation capacity of holiday centres, camp sites, and camp sites for tents. The accommodation capacity increased in the case of hotel facilities approximately 2.5 times in the years 2000-2013 (tab. 1).

Hotel facilities (hotels, guest houses, and motels) are an accommodation base with the highest level of services. In the Lublin Province they accounted for the biggest percentage of mass accommodation facilities (tab. 1). In 2013, a total of 133 facilities were in operation ( $46.7 \%$ of the mass accommodation base). They also had the greatest accommodation capacity $(7,488$, that is $40.1 \%$ of the total capacity of all facilities in the Province).

In the Lublin Province, hotel facilities were dominated by hotels, i.e. 76 facilities (tab. 1). They constituted $26.7 \%$ of the mass accommodation facilities in the Province and were particularly represented by facilities of lower categories ( 3 stars -41 facilities, 2 stars - 16 facilities, 1 star -7 facilities). In 2013, approximately 415,000 persons were accommodated in the facilities, i.e. $55.9 \%$ of all persons staying in mass accommodation facilities that year. Approximately 580,000 overnight stays were booked by tourists in hotels in 2013, constituting approximately $37.5 \%$ of the total number of the overnight stays that were booked in the Lublin Province (tab. 2).

The hotels examined had a high degree of concentration in terms of their distribution. The greatest number of hotels were located in Lublin (16 hotels) and in the Puławy (Puławski) District (12 facilities), where they constituted $36.8 \%$ of the hotel base of the Lublin Province, accounting for $47.1 \%$ of the accommodation capacity. In 2013, the facilities accommodated approximately $50.2 \%$ of all persons staying at hotels in the Lublin Province. The hotels provided accommodation for approximately 300,000 overnight stays, i.e. $51.7 \%$ of the total number of stays in the entire Province (tab. 2).

\section{Description of hotels offering spa facilities and services}

Hotels offering spa services in addition to accommodation services constituted $19.5 \%$ of the total number of hotel facilities in the Lublin Province. They were concentrated particularly in the Puławy (Puławski) District (in Nałęczów, Kazimierz Dolny, Janowiec, and Puławy) and in Lublin. A limited number of facilities were available in Janów Lubelski, Zamość, Leśna Podlaska, Dębowa Kłoda, Włodawa, Tomaszów Lubelski, Susiec, and Poniatowa (fig.1, tab. 3). The hotels analysed featured a relatively high standard. They were dominated by facilities categorised as three- and four-star hotels. In terms of their accom- modation capacity, small facilities were predominant: up to 50 guests could be accommodated in twelve of the facilities and from 51 to 100 guests could stay in eight of them. Only one hotel (Król Kazimierz Hotel \& Spa) offered an accommodation capacity of more than 200 guests. Spa services in the hotels included in the analysis have mostly been introduced in recent years, including seven in the years 2013-2014 and a further nine in 20112012. Spa services were first offered at Feniks Villa \& Spa in Raj in 1991.

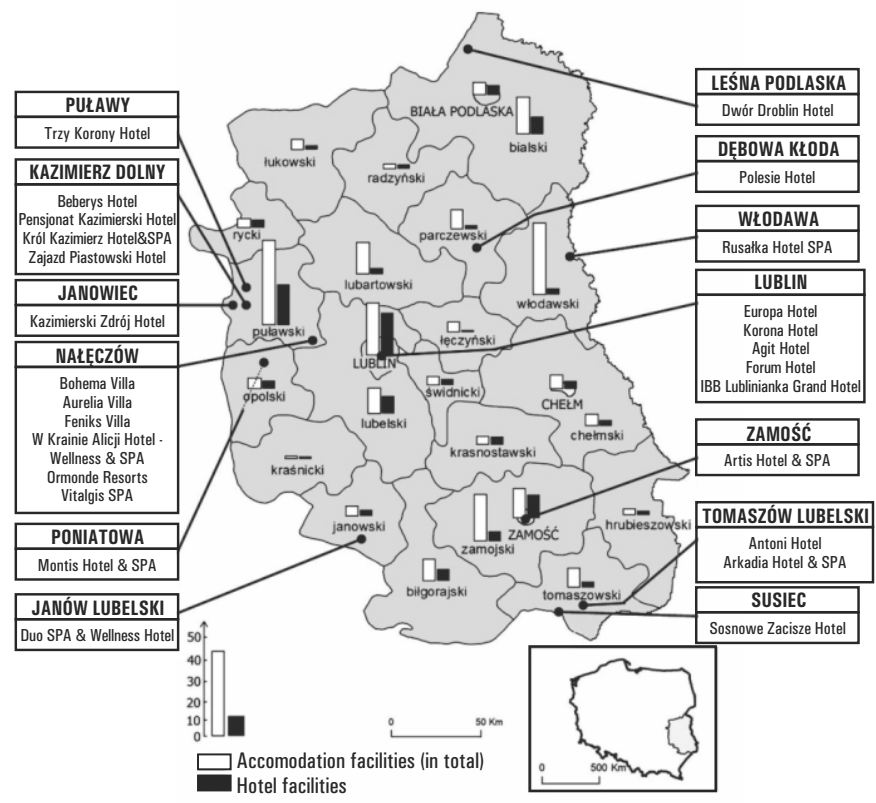

Source: Own elaboration based on data of the Central Statistical Office, Central Record of Hotel Facilities, and Panorama Firm and Polskie Książki Telefoniczne company directories.

Figure 1. Facilities offering spa services included in the analysis in the context of the total number of mass accommodation facilities and hotel facilities in the districts and cities with district status in the Lublin Province

The spa services and facilities offered at the hotel facilities in the Lublin Province analysed are presented with consideration of four types of services (fig. 2), i.e.: hydrotherapy, thermotherapy, massage, and other. The adopted qualitative criterion was a group of 22 services, including five services in the hydrotherapy segment (steam bath, hydro massage, Scottish shower, hot tub, and swimming pool), four in thermotherapy (Finnish sauna, steam bath, banya, and low temperature treatments), three in massage (oriental, using devices, and using cosmetics), and ten services categorised as "other" (peloid therapy, salt cave, solarium, cosmetology, aesthetic medicine, fitness, aromatherapy, chromotherapy, and physiotherapeutic capsules). The services offered in 26 facilities featured a total of 267 products, including 64 in hydrotherapy, 43 in thermotherapy, 59 in various forms of massage, and 97 other products. 


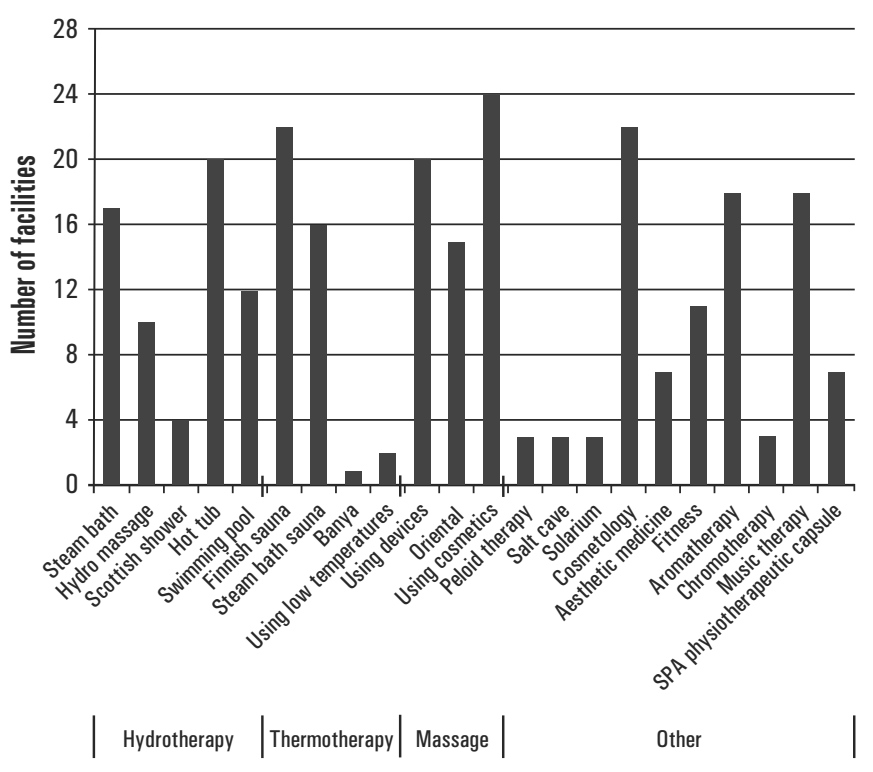

Source: Own elaboration based on data collected by means of a diagnostic survey.

Figure 2. Number of spa hotel facilities providing particular types of services among the facilities included in the analysis

The most comprehensive offer was provided by Artis Hotel \& Spa in Zamość. It includes 16 treatments (fig. 3). Two services less were offered by Vitaligs Spa at Dwór Nałęczowski. The smallest selection of services was available at Trzy Korony Hotel in Puławy, where only two treatments were offered (Finnish sauna and massage using cosmetics). A relatively poor offer (4 services each) was recorded for the two following hotels: Arkadia Hotel \& Spa in Tomaszów Lubelski (hot tub, Finnish sauna, swimming pool, and a salt cave), Berberys Hotel in Kazimierz Dolny (hot tub, Finnish sauna, massage using cosmetics, and cosmetology), and Europa Hotel in Lublin (massage using devices, massage using cosmetics, cosmetology, and aesthetic medicine).

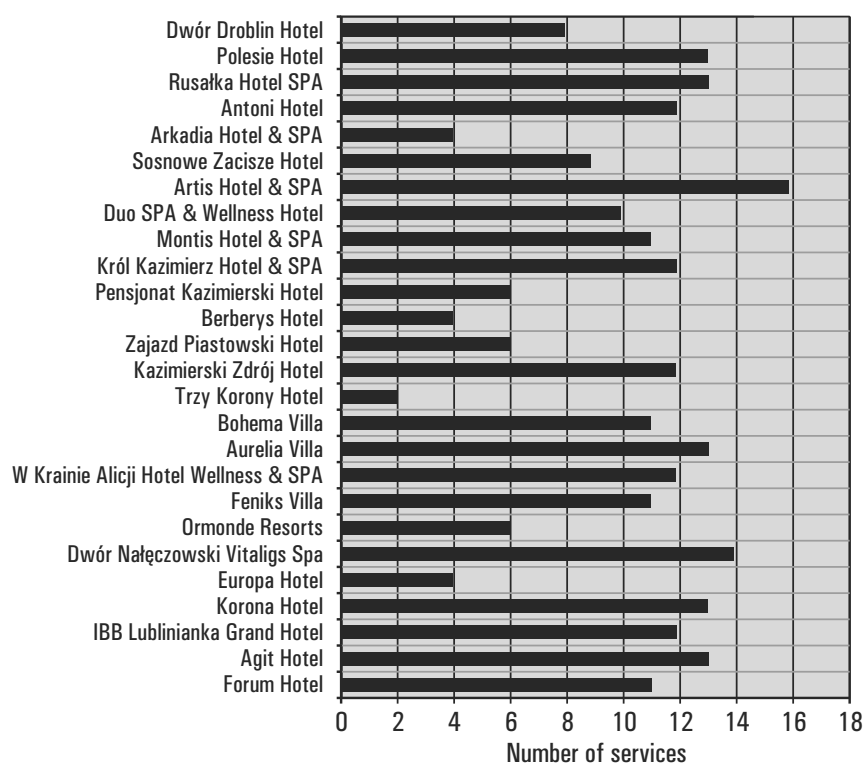

Source: Own elaboration based on data collected by means of a diagnostic survey.

Figure 3. Number of services provided in the spa hotel facilities included in the analysis
The majority of the forms of therapy in the spa hotel facilities analysed (fig. 2) included massage using cosmetics (in 24 facil ities), Finnish sauna (in 23 facilities), and cosmetic services (in 22 facilities). Hot tubs and massage using devices were also popular: they were recorded in 20 facilities. The treatment offered the most seldom was banya, which was only provided at the Dwór Droblin Hotel in Leśna Podlaska. Only two facilities offered treatments using low temperatures (Artis Hotel \& Spa in Zamość and Forum Hotel in Lublin). Only three facilities offered the following: peloid therapy (Montis Hotel \& Spa in Poniatowa, W Krainie Alicji Hotel Wellness \& Spa in Nałęczów, and Agit Hotel in Lublin), salt caves (Arkadia Hotel \& Spa in Tomaszów Lubelski, Artis Hotel \& Spa in Zamość, and Zajazd Piastowski Hotel in Kazimierz Dolny), and chromotherapy (Rusałka Hotel Spa in Włodawa, Vitaligs Spa at Dwór Nałęczowski in Nałęczów, and Lublinianka IBB Grand Hotel in Lublin).

\section{Discussion}

The distribution of the accommodation base in the Lublin Province is determined among others by the attractiveness of a given area in terms of tourism, including the existing tourism products, administrative and economic importance of a given city or town, and the accessibility of transport [24, 25]. Therefore, accommodation facilities are particularly concentrated in areas of high environmental and cultural value, which are simultaneously distinguished by a high number of tourists that visit them [26]. Hotel facilities constitute an important segment of the accommodation base. Their primary task is to create an accommodation base for tourists and provide hotel services [27]. Apart from basic services, the modern hotel industry offers a number of additional services, including those having to do with wellness [28]. Research has shown that spas, which are one of the most dynamically developing segments of health tourism, are an important product in this niche [6]. J. Owsiak [13] stated that investing in spa facilities and offering spa services helped hotels boost the attractiveness of the services they offered, build a positive image, increase the average level of occupancy and the average price of rooms, enhance the marketing advantage over their competition, promote the use of the facility during the whole year (higher occupancy by guests using spa services is recorded in spring and autumn), increase their revenues from gastronomy, and finally increase the total income from their business activity (spa services are also available to guests not using the accommodation offered by the hotels). According to analysts, spa and wellness services generate the highest profits for the hotel industry, following accommodation and gastronomy services $[2,5,29,30]$. A similar tendency had been observed by the managers of the facilities in the Lublin Province included in the analysis, who assessed the sales of wellness services in comparison to the remaining services offered as good or very good in 11 cases.

The spa services offered in hotel facilities (particularly hotels) constitute a complex product [10, 29]. This product has the form of several goods and services called a package (e.g. an overnight stay combined with a treatment offer). Including wellness treatments in the services offered by hotels often enhances their prestige and reputation as well as giving them a competitive advantage on the market. Spa facilities compete in the number of services offered and their original character. The objective is securing a good position in the market and being competitive.

Among the five hotels in Lublin offering a wide range of spa services which were analysed only Korona Hotel offered hydro massage and a swimming pool. Similarly to Agit Hotel, this hotel also provided its clients with oriental massage and peloid therapy. The Agit and Forum Hotels were the only ones in Lublin to offer solarium and fitness. Lublinianka IBB Grand Hotel was 
also competitive in its offer. Only this hotel offered a spa capsule and chromotherapy. The hotels in Lublin which were examined did not provide three out of the 22 treatments considered, namely Scottish shower, banya, or salt caves.

The offer of particular hotels in Kazimierz Dolny and Nałęczów also included services that gave them a competitive advantage. In Kazimierz Dolny, only Król Kazimierz Hotel offered hydro massage, massage using devices, or music therapy. Only Zajazd Piastowski Hotel had a salt cave. Among the four facilities in Kazimierz Dolny included in the analysis, only these two facilities had a swimming pool and offered oriental massage and aromatherapy. The facilities in Kazimierz Dolny did not offer nine treatments, namely Scottish shower, banya, treatments using low temperature, peloid therapy, a solarium, aesthetic medicine, fitness, chromotherapy, and a spa capsule. In Nałęczów, none of the six facilities analysed offered banya, treatments using low temperature, or a salt cave; however, the services offered by particular facilities can be seen as competitive. For instance, Dwór Nałęczowski Hotel provided its clients with an opportunity to use a Scottish shower, a solarium, and chromotherapy. This facility, Feniks Villa, and W Krainie Alicji Hotel offered a swimming pool, fitness, and a spa capsule. W Krainie Alicji Hotel was the only one providing peloid therapy. None of the facilities in Nałęczów offered banya, treatments using low temperatures, or a salt cave.

The results of the study suggest that spa hotel facilities in the Lublin Province have made use of scientific achievements in physiotherapy and health resort medicine to a great extent. However, the range of the health and beauty treatments offered, including those improving beauty, prove that they focused on forms of treatment supporting wellness and relaxation. The commercial nature of the services offered at spas makes it possible to considerably expand the scope of physiotherapy by introducing methods related to psychotherapy, such as aromatherapy or chromotherapy.

In the facilities analysed, not only were treatments supporting relaxation and wellness important but so were those improving the appearance. This is the objective of various forms of massage, baths, or peloid therapy. In order to attract a greater number of clients, spas often offer treatments adopted from other medical and cultural traditions, e.g. from Chinese, Thai, Indian, or Turkish medicine [9].

It should be emphasised that expanding the offer by introducing modern treatments according to the requirements of the market is not only aimed at obtaining a competitive advantage, but also contributes to popularising health prophylaxis and developing the market of wellness services [31]. Wellness services provided in accommodation facilities are popular not only among tourists but also increasingly with local communities.

\section{Conclusions}

The tourism accommodation base in the Lublin Province was highly diverse in terms of its features. It was dominated by hotel facilities (hotels, guest houses, and motels), whose total number was 133 in 2013. They constituted $46.6 \%$ of the mass accommodation facilities in the Lublin Province, and provided $40.1 \%$ of the accommodation capacity in the Province. This type of accommodation base hosted $52.2 \%$ of all guests staying in mass accommodation facilities in 2013. Every fourth mass accommodation facility in the Lublin Province was a hotel and 76 facilities were recorded in 2013. They provided $26.5 \%$ of the accommodation capacity of the Province. Over the year, they hosted $37.5 \%$ of the total number of guests of mass accommodation facilities.

Hotels and guest houses offering spa services in addition to accommodation services constituted $19.5 \%$ of the total number of hotel facilities in the Lublin Province. They were particularly concentrated in the Puławy (Puławski) District (in Nałęczów, Kazimierz Dolny, Janowiec, and Puławy) and in Lublin. The spa hotel facilities differed in terms of their product offer. The most comprehensive range of services (18 treatments) was recorded for Artis Hotel \& Spa in Zamość, which has operated on the spa market since 2011. A relatively rich package (14 treatments) was offered by Vitaligs Spa at Dwór Nałęczowski Hotel which launched its spa services in 2001. The most limited selection was provided by Hotel Trzy Korony in Puławy, where only two treatments were available.

The facilities considered in the analysis competed with each other in the number of services offered and their original character. The spa services offered by the hotel facilities in the Lublin Province were presented according to four categories: hydrotherapy, thermotherapy, various forms of massage, and other services. The basic offer in the facilities analysed included three services: classic massage, Finnish sauna, and oriental massage (recorded in more than 20 facilities), i.e. services improving general wellness. The fewest facilities offered treatments using low temperatures, salt caves, peloid therapy, and chromotherapy. Considering the area of concentration of hotel facilities offering spa services, the facilities in Lublin, Nałęczów, and Kazimierz Dolny had a competitive advantage in the Lublin Province.

Forecasts concerning people's perception of their own appearance and pro-health activity suggest that the demand for this kind of services will increase. Spas could become one of the most attractive tourism products in the Lublin Province, creating an opportunity for the general development of the tourism sector. The spa services market in the Lublin Province is an example of a market where innovative activities that enrich the range of products offered to tourists in the Province are undertaken.

\section{Literature}

1. Sallmann N. (2010). Megatrend of wellness \& spa in the leisure and hotel industry market in the $21^{\text {st }}$ century. Kraków: PAG. [in Polish]

2. Szczepanowska E., Kaczor B., Pawełek K. (2012). The products offered by selected spa hotels at the Polish-German border - a comparative analysis. Prace Naukowe Uniwersytetu Ekonomicznego 12(258), 34-46. [in Polish]

3. Mroczek- Czetwertyńska A., Rapacz A., (2012). Demand for spa \& wellness services and the capacity to meet this demand based on the example of Lower Silesia. Zeszyty Naukowe Uniwersytetu Szczecińskiego 699 Ekonomiczne Problemy Usług 84, 579-592. [in Polish]

4. Kapczyński A., Szromek A.R. (2008). Hypotheses concerning the development of Polish spas in the years 1949-2006. Tourism Management Elsevier 29, 1035-1037.

5. Hałaczkiewicz J. (2008). The concept of spa in the hotel industry. In W. Gaworecki, Z. Mroczyński (eds.), Tourism and sport for all in the promotion of healthy lifestyle (pp. 508-520). Gdańsk: WSTiH. [in Polish]

6. Mroczek A. (2008). The role of spa \& wellness centres in the promotion of healthy lifestyle. In W. Gaworecki, Z. Mroczyński (eds.), Tourism and sport for all in the promotion of a healthy lifestyle (pp. 548-555). Gdańsk: WSTiH. [in Polish]

7. Dryglas D. (2010). Development of spa facilities as innovative health tourism products in Poland. In A.R. Szromek (ed.), Health resorts and their importance in the tourism sector (pp. 151-166). Kraków: Proksenia. [in Polish]

8. Lubowiecki-Vikuk A. P. (2008). Spa \& wellness - a megatrend in modern health tourism. In W. Gaworecki, Z. Mroczyński (eds), Tourism and sport for all in the promotion of healthy lifestyle (pp. 540-547). Gdańsk WSTiH. [in Polish]

9. Kasprzak W., Mańkowska A. (2008, 2010). Physiotherapy, 
health resort medicine, and spa. Warszawa: PZWL. [in Polish]

10. Maj A. (2008). Visits to the spa - a new type of recreation in Poland? In W. Muszyński, M. Sokołowski (eds), Homo creator or homo ludens? New forms of activity and spending free time (pp. 213-225). Toruń: Adam Marszałek. [in Polish]

11. Łęcka I. (2003). New trends in health tourism. Prace i Studia Geograficzne 32, 173-190. [in Polish]

12. Januszewska M., Nawrocka E., Oparka S. (2010). Health resort tourism, tourism in health resorts. In A.R. Szromek (ed.), Health resorts and their importance in the tourism sector (pp. 91-114). Kraków: Proksenia. [in Polish]

13. Owsiak J. (2012). Selected issues in health tourism (the spa and wellness sector) in Poland. Problemy Turystyki i Rekreacji 12(4), 20-34. [in Polish]

14. Mak A.H.N., Wong K.K.F., Chang R.C.Y. (2009). Health or Self-indulgence? The Motivations and Characteristics of Spa-goers. International Journal of Tourism Research, Special Issue: Extraordinary Experiences in Tourism 11(2), 185199.

15. Spivack S.E. (1997). Health Spa development in the US: A burgeoning component of sport tourism. Journal of Vacation Marketing 4(1), 65-77.

16. Tucki A., Hadzik A. (2013). Analysis of the possibilities of the development of health tourism in the Lublin Province in the context of the smart specialisation of the Province in the field of medical and pro-health services. Lublin: Urząd Marszałkowski Województwa Lubelskiego. [in Polish]

17. Wojnarowski J.A. (2012). New trends in the hotel industry. Zeszyty Naukowe WSSP 14, 137-172. [in Polish]

18. Central Statistical Office. Retrieved October 15, 2014 from http://stat.gov.pl/bdl/app/dane_podgrup.dims?p_id=147058 \&p_token $=0.02113337372429669$. [in Polish]

19. Central Record of Hotel Facilities. Retrieved November 15, 2014 from http://turystyka.gov.pl/cwoh/index. [in Polish]

20. Polish Company Directory. Retrieved November 15, 2014 from http://panoramafirm.pl/szukaj?k=spa\&l=lubelskie. [in Polish]
21. Polish Company Directory. Retrieved November 15, 2014 from http://www.pkt.pl/spa/lubelskie/3-1. [in Polish]

22. Berg B.L. (2001). Qualitative Research Methods for the social sciences. Long Beach: California State University.

23. Sztabiński P., Sztabiński F., Sawiński Z. (2004). New methods and new approaches in social sciences. In P.B. Sztabiński, F. Sztabiński, Z. Sawiński (eds), PAN (pp. 119-139). Warszawa: IFiS. [in Polish]

24. Świeca A., Krukowska R., Tucki A. (2007). Possibilities for the Development of Tourism in the Lublin Region. In G. Godlewski, M. Bochenek (eds), Tourism Theory - Conditions Experiences (pp. 69-98). Biała Podlaska: AWF ZWWF.

25. Tucki A., Skowronek E., Krukowska R., (2012). Size and diversity of the accommodation base as a determinant of the demand for tourism services in the Lublin Province. Zeszyty Naukowe Uniwersytetu Szczecińskiego 699 Ekonomiczne Problemy Usług 84, s. 395-408. [in Polish]

26. Lijewski T., Mikułowski B., Wyrzykowski J. (2008). Geography of tourism in Poland. Warszawa: PWE. [in Polish]

27. Panasiuk A., Szostak D. (2009). Hotel industry. Services - exploitation-management. Warszawa:PWN. [in Polish]

28. Eberhardt A. (2007). Physiological basis of active recreation. Warszawa: Wyższa Szkoła Ekonomiczna. [in Polish]

29. Rapacz A., Mroczek- Czetwertyńska A. (2014). Possibilities and directions of the development of the spa and wellness market in Lower Silesia. Zeszyty Naukowe Uniwersytetu Szczecińskiego 806, 247-262. [in Polish]

30. Kaleta A. (2010). The spa \& wellness hotel industry as an evolving product of the leisure industry - selected aspects. Zarzadzanie i Finanse Wydziału Zarzadzania Uniwersytetu Gdańskiego 1, 361-371. [in Polish]

31. Milewska M., Włodarczyk B. (2009). Hotel industry: basic information. Warszawa:PWE. [in Polish]

Submitted:January 23, 2015

Accepted:June 8, 2015 